Print ISSN: 2288-4637 / Online ISSN 2288-4645

doi:10.13106/jafeb.2020.vol7.no6.047

\title{
The Impact of Financial Inclusion on Financial Stability in Asian Countries
}

\author{
Manh Hung PHAM${ }^{1}$, Thi Phuong Linh DOAN ${ }^{2}$ \\ Received: March 25, 2020 Revised: April 11, 2020 Accepted: May 07, 2020
}

\begin{abstract}
This paper intends to explore the relationship between financial inclusion and financial stability under the scope of Asian economies. The linkage will be thoroughly investigated with country-level and bank-level data of 42 countries in three separate years: 2011,2014 , and 2017. In this study, an inclusive financial system is assessed by two dimensions: usage of financial services and access to the financial system. Usage of financial services ranges from account to credit, savings and payment services. Access to financial system measures the financial outreach where individuals can use financial services. Meanwhile, financial stability, which proxied by Bank Z-score is regarded as the dependent variable. We apply fixed effects regression and random effects regression to capture the impacts of financial inclusion upon financial stability. To enhance the robustness of the model, the Feasible Generalized Least Squares (FGLS) regression is therefore adopted as the solution for the random effects regression. The empirical findings exhibit an overall weak positive influence of financial inclusion on financial stability. The research results also provide both financial institutions and governments with insightful information, which helps them to have an appropriate financial development strategy, improve the regulatory framework and consequently enhance financial stability for the whole system.
\end{abstract}

Keywords : Financial Inclusion, Financial Stability, Panel Regression, Asian Countries.

JEL Classification Code: G21, G18, O11, O16.

\section{Introduction}

Since the early 2000s, the concept of financial inclusion has attracted attention from governments and central banks worldwide for its contribution to the goal of economic and financial developments. Greater entry to formal financial services in households and firms levels in both developing and developed countries helps to reduce poverty and foster economic positions. Simultaneously, in the aftermath of

${ }^{1}$ First Author and Corresponding Author. Research \& Advisory Division, Banking Academy, Vietnam [Postal Address: 12 Chua Boc Street, Quang Trung Ward, Dong Da District, Hanoi, 115000, Vietnam] Email: hungpm@hvnh.edu.vn

${ }^{2}$ International School of Management and Economics, National Economic University, Vietnam

(c) Copyright: The Author(s)

This is an Open Access article distributed under the terms of the Creative Commons Attribution Non-Commercial License (http://Creativecommons.org/licenses/by-nc/4.0/) which permits unrestricted noncommercial use, distribution, and reproduction in any medium, provided the original work is properly cited. the 2007-2009 global financial crisis, financial stability issue has emerged and gained interests from researchers and policymakers across the globe due to the realization of mitigating systemic financial risk and enhancing financial stability to the strategy of sustainable developments of countries. This raises the issue of whether inclusive finance and financial stability complement each other, particularly whether financial inclusion stimulates or endangers financial stability.

According to the literature review, previous studies show the inconsistent view of the implications of financial inclusion on financial stability. Filling this literature gap is one of the main goals of this study. Moreover, while there has been a wide range of research about the nexus in which financial inclusion could influence financial stability, not much empirical research could investigate such relationship in Asian countries. Therefore, this research will add to the existing literature with reconfirmation or new evidence to the previous ones. Research results also provide both financial institutions and governments with insightful information, which helps them to have an appropriate financial 
development strategy, improve the regulatory framework and consequently enhance financial stability for the whole system. Given this context, this research aims to answer the two following questions: (i) does the progress to financial inclusion tend to enforce or diminish financial stability? and (ii) what are the reasons explaining the relationship between financial inclusion and financial stability?

The remainder of this research will be organized as follows: Section 2 provides relevant literature for the relationship between financial inclusion and stability. Section 3 delivers a description of variables, model specification, and empirical estimation technique. Section 4 presents and discusses the empirical outcomes and robustness checks obtained from panel estimation processes. Section 5 discusses the implication of the main findings and the last parts of the paper focus on concluding remarks.

\section{Literature Review}

\subsection{Financial Stability}

Even though there are numerous definitions of financial stability, most definitions observe the term in a common view. As defined by ECB (2012), financial stability is the state where the financial system, consisting of financial intermediaries, financial markets and related market infrastructures, can withstand the shocks. Therefore, it may reduce the possibility of disruptions of the financial intermediation processes, which are sufficiently severe to significant impairments in the financial system. According to Ahmad (2018), a stable financial system can allocate resources efficiently, managing financial risks relating to the financial system and eliminate undesirable price movements of real or financial assets that will affect monetary resilience. The financial imbalance that emerges endogenously or because of unforeseen events is also eliminated in a stable financial system. In the cases of shocks, the system will absorb through self-corrective mechanisms that prevent adversity from resulting in disruptive influences on the real economy and other financial systems. To achieve sustainable economic growth, financial stability is the essential policy element since most transactions in the economy are conducted through the financial system.

\subsection{Financial Inclusion}

Financial inclusion is diversely defined based on their objectives and measurements. For objectives, Hannig and Jansen (2010) and García (2016) agreed that financial inclusion aims to attract the 'unbanked' population into the formal financial system, where they can access financial services including credit, savings, payment, insurance and so on. In terms of measurements, financial inclusion can be categorized through following groups: access (the ability to get access and use financial services/products of formal institutions), quality (the involvement of available financial services/products to customer demands, including customer choices, customer understanding, and customer attitude), usage (the permanence and depth of services/products used in financial system) and impact (the efficiency of financial services/products contributing to consumers' life improvement) (World Bank, 2014; Park \& Mercado, 2018).

\subsection{The Impact of Financial Inclusion on Financial Stability}

Studies on the possible impacts of financial inclusion on financial stability are relatively new and thin. The literature on such a relationship provides contradicting aspects of how these concepts are associated theoretically.

According to Khan (2011), there are some fundamental ways illustrating the positive influences of financial inclusion to stability. First, financial inclusion fosters an extensive savings intermediation and facilitates compositional changes in the financial system as it allows more opportunities for financial institutions in operating in newly created businesses or expanded markets. When the balance sheet of the whole sector increases with diversity and broader participation of economic agents, it contributes to higher potential economic resilience. Second, financial inclusion provides a more robust base of retail funding for a financial institution, particularly for banks. Retail deposits as buffers for borrowed funds increase the sector's stability because the lower-income appears to display steady financial behaviors in the boom-bust cycle regarding deposit keeping and loan repayment. Therefore, during financial distress periods, such clients' deposits become a continued funding source, especially when banks run out of other credit sources. Third, financial inclusion restricts the fact that a large informal sector can create impairments to the effectiveness of monetary policy transmission. It facilitates more formal participation of financially excluded agents of the economy such as households and small businesses, who typically make independent and unaffected financial decisions from supervised monetary bodies. Prasad (2010) also denotes that inadequate access to credit of small and medium-sized enterprises and small-scale entrepreneurs produce undesirable effects on overall unemployment since these businesses demand labor and financial intensity in their operations. By including them in the financial sector, these funded firms can expand their operations and produce more output to the economy.

Using cross-country panel data over the 2005-2011 period, with GMM dynamic panel estimation, Morgan and Pontines (2014) proxied financial inclusion with the share of 
SMEs credit total commercial banks' credit and proportion of SMEs' borrowers to total commercial banks' borrowers. Financial stability is measured by banks' NPL and banks' Z-scores. The authors found that a higher proportion of SMEs lending is associated with lower non-performing loans and lower probability of default of financial institutions. Similar outcomes were also found with a higher number of SME borrowers. This implies that the policy efforts to greater financial inclusion would create side-benefits to the financial stability contributions. Han and Melecky (2013) investigated the financial inclusion - stability relationship in 95 countries by applying World Bank data and cross-sectional regressions method, in which financial inclusion is measured as the access to and the use of deposits before the 2008 crisis, and the proportion of individuals using bank deposits in 2011. The dependent variable is the maximum decline of bank deposits growth in 2006-2010. The conclusion was that: broader access to and use of bank deposits can considerably mitigate the withdrawals during crisis periods, enhance banks' proportion of stable funding and lead to a reduction in total bank deposit volatility in times of economic recessions. Additionally, estimated coefficients on the variables suggested that a $10 \%$ rise in the share of individuals having deposit access would lower the deposit drops up to $8 \%$, implying a promoted financial stability in both the banking system and financial sector. Also, study of Tran and Nguyen (2020) shows that the impact of financial development on Z-score is significantly positive, whereas its effect on non-performing loans is significantly negative, thus on average reduces bank risk.

In contrast with positive relationships, some empirical evidence advocates the negative impact of financial inclusion on stability. Using cross-country data with a panel regression approach, Sahay et al. (2015) studied the overall effect of financial development, which combines a multidimensional measure including depth, access, and efficiency, to economic growth and financial stability among 200 observations. Noticeably, the authors found a significant negative effect on financial stability and argued that, in countries with lower bank oversights and compliance of Basel Principles of Effective Banking Supervision, access to credit is positively linked with a decline in bank buffers. This tendency is much greater when the decline of financial safeguards is faster in weaker supervision countries. Whereas, access to and use of other financial services besides credit does not influence financial stability adversely since the effects are still inconclusive.

The World Bank (2012) in its Global Financial Development Report also provided evidence for the inclusion-stability negative relationship. Using Financial Access Survey data, the paper shows a better correlation between two concepts in low-income as well as lowermiddle-income countries where financial inclusion issues are more severe. There, financial access is proxied by the number of loan accounts in commercial banks per 1000 adults, and financial stability is represented by banks' NPLs along with risk premium on lending ratio. The results show statistically negative correlations between these measurements. Also, with bank capital/assets, there is a similar negative outcome: higher loan penetration is associated with lower capitalized banks. This implied that high-income countries with high financial access levels encounter related factors that impose higher instability, such as lower capital requirements or higher immoral incentives to risk management. Furthermore, the data from the research also revealed that countries with a higher competitive banking sector achieve greater deposit penetration and higher financial stability.

Moreover, some literature presents viewpoints that when financial inclusion is linked to rapid or ineffective inclusive expansion from unregulated parts in the financial sector, systemic risks would increase. Mehrotra and Yetman (2015) argued that one approach to increase financial inclusion is to incentivize banks with aggressive credit expansion to the poor and uncreditworthy households who do not have sufficient attention to loan repayment. As a result, credit standards in the banking system could be compromised and deteriorated, the screening ability before disbursement could reduce, leading banks to absorb customers with low credit quality (Igan \& Pinheiro, 2011). Khan (2011) indicated that improvements in financial inclusion may trigger growth from unregulated institutions of the financial sector.

Finally, some research papers produce inconsistent or synergistic results between the two concepts. Ardic et al. (2013) argued that: statistically, financial inclusion (measured as deposit account penetration) shows neither positive nor negative correlations with both stability data from FAS and GFDD. The explaining reason may result from the inadequacy of solid data, but it also means such a relationship is not simply straightforward. Cihak et al. (2016) studied the overall association, where financial inclusion is classified into economic agents (firms versus individuals) and financial services (account, saving, credit, insurance). Financial stability is reflected under three groups: resilience, volatility or banking crisis. Their concluding results have important implications: First, although average correlation proposes a prevailing inclusion-stability trade-off, the empirical distributions of pairwise correlations reveal a high probability of both trade-off and almost equally synergies in cross-country experience. Especially, this distribution seems different in the firm and individual inclusion levels. Second, in general, financial inclusion indeed aids financial stability in normal times, however, under different stability dimensions, there are some insignificant relationships in particular. For example, high resilience or low volatility 
do not appear much significant to the financial inclusion of both economic agents in any financial services.

\section{Data and Methodology}

\subsection{Data}

The study employed data sources with high reliability mainly from Global Financial Development Database (GFDD) of World Bank for resilience stability indicator Bank Z-score and Global Findex Database (GFD) of World Bank for individual-level inclusion indicators.

GFDD is an extensive dataset consisting crosscountry time-series data, categorized by financial system characteristics variables featuring financial depth, financial access, financial efficiency and financial stability from 203 countries.

GFD is the world's most inclusive data provider of information about individuals' uses of and accesses to both formal and informal financial services such as saving, borrowing, using accounts and making payments. Up to present, three comprehensive datasets of GFD has been published every three years since 2011, summarizing country-level indicators of financial inclusion.

On the basis of data availability, the author collected relevant data on variables of financial inclusion and financial stability of 42 Asian countries in three separate years: 2011, 2014 and 2017.

\subsection{Variables Selection}

\subsubsection{Financial Stability}

The research aims to clarify the impact of financial inclusion on financial stability, therefore, financial stability is regarded as the dependent variable. This paper employed data for resilience measurements, proxied by Bank Z-score. Having been extensively used by many researchers as an indicator of financial stability including Han and Melecky, 2013; Morgan and Pontines, 2014 and others, Bank-Z score is a statistical measurement of the default probability of a country's banking sector, which is commonly used as a financial stability indicator at the level of individual institutions.

\subsubsection{Financial Inclusion}

To proxy for financial inclusion, the paper follows the variables selection approach from Cihak et al. (2016) and Ghosh (2008). Accordingly, an inclusive financial system should be classified into two dimensions: usage of financial services and access to the financial system. In which, usage of financial services ranges from account, to credit, savings and payment services. Access to financial system measures the financial outreach where individuals can access to financial services. A focused scope of variables will be placed on the banking system for two reasons: First, the banking sector accounts for the most part in funds intermediation in the majority of countries' financial systems. Second, statistical data for the banking sector is easier to obtain as compared to other non-bank services providers (Ghosh, 2008).

\section{a. Usage of financial services indicators}

Credit: At a certain level, credit plays a crucial role in supporting economic growth through the credit intermediation channels. Expanding credit access also provides individuals a diverse range of credit services to finance their needs, which leads to greater stability of the overall financial system. Furthermore, this positive effect of credit to financial stability can also be recognized in financial systems with high supervision levels from the central government, where compliance of financial conducts (for example, Basel principles for required banking sector) is highly encouraged (Garcia, 2016). However, excessive credit growth from increased inclusion can adversely affect the resilience of the financial system. As argued by Dienillah, Anggraeni and Sahara (2018), the instability following financial inclusion comes from relatively unregulated and less credit-worthy borrowers, as well as from unstable lending activities outside the banking systems. Consequently, this deteriorates the credit standards applied for financial institutions and triggered a systemic risk for the whole financial system (Ahmad, 2018). Based on this explanation, the paper will examine whether available variables related to inclusive credit services, including Credit card $(\%$ age $15+)(\mathrm{CRE})$ and Loan from a financial institution (\% age $15+$ ) (BOR) may have either positive or negative effect on financial resilience.

Saving: Saving is an important factor that positively enhances the stability level in the financial system from microto macro-levels, under both direct and indirect channels. At individual levels, small savers have a tendency of maintaining persistent financial behaviors, which essentially make their deposits act as a stable funding source for formal financial institutions when these institutions' financing falls below the regulatory requirement rates or is unable to roll over. (Khan, 2011; Cull \& Kunt, 2012). For banks particularly, savings in the form of retail deposits can generate a firm capital base for banking operation that is less sensitive to market and economic changes, and act as a buffer absorbing liquidity risk in times of financial distresses (Han \& Melecky, 2013). Therefore, the variable 'Adults saving at a financial institution in the past year (\%)' (SAV) will be called for relevance in the model and thus, expected to have a positive impact on stability. 
Account: Account ownership at financial institutions is discussed having a positive influence on financial resilience. Increasing account usage can encourage more efficiency of intermediation process, reduce the related costs and improve the transmission of monetary policies. More specifically, more usage of formal account can positively assist saving and payment services as it encourages clients to shift their savings from physical assets and cash into deposits, and helps customers to smooth their consumption over time. This makes interest rates more effective as a policy tool and it may facilitate central banks' efforts to maintain financial stability (Hawkins, 2006). For this reason, variable Account at A Formal Financial Institution (\% Age 15+) (ACC) is added in the model and is expected to obtain a positive sign.

Payment: Increasing modern digital platforms such as mobile devices, personal computers or the Internet has facilitated easier payment through which individuals can perform payment transactions for goods and services, besides visiting traditional payment networks such as banking institutions or directly interact with the financial service providers. This growing trend may promote efficiency in the payment system, as it ensures smooth functioning as crucial to overall efficiency, thus promote the overall stability (Ozili, 2018). However, it also leads to policy implications for traditionally bank-focused risk prevention. The risks proposed from electronic payment services on financial stability can be varied from spearfishing, cyber-attacks to money laundering as well as terrorist financing risks, as more payments are being carried out outside from the banking system, thus reduce customer believes in the financial sector (Resendiz, 2018). On that basis, the variables including Electronic payments used to make payment (\% age 15+) (ELP) and Debit card (\% age 15+) (DEB) are added in the model to examine the inclusion of payment services effect on stability state of financial system and are expected to have a negative or positive impact on financial stability.

\section{b. Access to financial system indicators}

Penetration: Penetration dimensions measure the depth level of financial access. Regarding to banking sector, the number of commercial bank branches per 100,000 adults (BRAN1) as well as the number of ATMs per 100,000 adults (ATM1) is the most relevant indicators as they capture the demographic penetration of the banking sector. Per-capita measurement of bank branches and ATMs proxy for the average number of people having access to each banks' physical outlets. A high level of demographic penetration suggests easier access from customers to branches or ATMs (Beck \& Kunt, 2005). As argued by Ghosh (2008), an increase in demographic penetration of banking services is linked to either a decrease or an increase in financial stability, as it depends on the services used by the individuals. For example, demographic availability expansion may lead banks to lose their compromisation on credit evaluation processes, which creates possibilities of higher loans default in the future.

Availability: Availability dimension concentrates on the geographically widespread reach of the financial sector since the physical distance to financial service providers is considered as a barrier to financial inclusion. As regard to banks' physical outlets, variables including the number of bank branches per 1,000 square kilometers (BRAN2) and number of ATMs per 1,000 square kilometers (ATM2) is the most relevant. Higher geographic availability of financial branches and ATMs means smaller physical distances, hence, easier geographic accesses (Beck \& Kunt, 2005). In the linkage to financial stability, Bofondi and Giorgio (2006) argued that lowering the availability of bank branches responses to rising delinquent loans can help to slow down the default rates of financial institutions. Ghosh (2008) indicated that both geographical and demographic bank branches and ATMs provision allows more opportunities distributed equally, especially for the poor area, and again, it depends on the services used that affect financial stability. Based on the above analysis of the expected impacts of financial inclusion components, we have the following table of the hypotheses to be assessed (see Table 1):

\subsubsection{Control Variables}

To capture a more precise effect of financial inclusion upon financial stability, the paper used a series of macroeconomic control variables that specify country characteristics conditions.

Firstly, as proposed by Morgan and Pontines (2014), GDP per capita is considered to have a positive effect on stability via financial inclusion. When GDP per capita goes up, this will promote a higher level of financial inclusion, thus would ultimately enhance stability level in the financial sector. Therefore, GDP per capita (denoted by GDP) is added in the model with an expected sign being positive.

Secondly, domestic credit positions provided by the financial sector can also influence the stability level. A higher percentage of domestic credit supplied by the financial system to various sectors (except for central government) implies a higher concentration of financial resources provided for non-governmental entities, which could result in a rise of financial instability probability (Morgan and Pontines, 2014). Therefore, Domestic Credit Provided by Financial Sector (\% of GDP) variable is assigned and expected to a negative sign.

Another control variable that is incorporated in the model is the size of the financial sector, measured by the broad money (M2) to GDP ratio. This indicator has been 
Table 1: Summary of independent variables

\begin{tabular}{|c|c|c|c|c|c|}
\hline Hypothesis & $\begin{array}{l}\text { Independent } \\
\text { variables }\end{array}$ & Abbreviation & $\begin{array}{c}\text { Data } \\
\text { sources }\end{array}$ & $\begin{array}{l}\text { Expected } \\
\text { sign }\end{array}$ & Reason(s) \\
\hline \multirow[t]{2}{*}{$\mathrm{H} 1$} & $\begin{array}{l}\text { Credit card (\% age } \\
\qquad 15+)\end{array}$ & CRE & $\begin{array}{l}\text { GFDD, } \\
\text { Global Fin- } \\
\text { dex }\end{array}$ & $+/-$ & \multirow{2}{*}{$\begin{array}{l}\text { (+): An increase in credit can facilitate } \\
\text { expanded operations of financial sector, } \\
\text { thus, increase economic resilience } \\
\text { (-): Credit expansion to under-rated } \\
\text { individuals can worsen bank lending } \\
\text { standard, increases NPLs, thus, } \\
\text { decreases financial stability }\end{array}$} \\
\hline & $\begin{array}{l}\text { Loan from a financial } \\
\text { institution (\% age } \\
15+)\end{array}$ & BOR & $\begin{array}{l}\text { GFDD, } \\
\text { Global Fin- } \\
\text { dex }\end{array}$ & $+/-$ & \\
\hline $\mathrm{H} 2$ & $\begin{array}{l}\text { Adults saving at a } \\
\text { financial institution in } \\
\text { the past year }(\%)\end{array}$ & SAV & $\begin{array}{l}\text { Global Fin- } \\
\text { dex }\end{array}$ & + & $\begin{array}{l}\text { Savings provide a more robust base of } \\
\text { retail funding for financial institutions, } \\
\text { thus, increase stability. }\end{array}$ \\
\hline $\mathrm{H} 3$ & $\begin{array}{l}\text { Account in a formal } \\
\text { financial institution } \\
(\% \text { age } 15+)\end{array}$ & ACC & $\begin{array}{l}\text { GFDD, } \\
\text { Global Fin- } \\
\text { dex }\end{array}$ & + & $\begin{array}{l}\text { Account ownership helps to facilitate } \\
\text { other financial services and promote the } \\
\text { effectiveness of monetary policies. }\end{array}$ \\
\hline \multirow[t]{2}{*}{$\mathrm{H} 4$} & $\begin{array}{c}\text { Debit card (\% age } \\
15+)\end{array}$ & DEB & $\begin{array}{l}\text { GFDD, } \\
\text { Global Fin- } \\
\text { dex }\end{array}$ & $+/-$ & \multirow{2}{*}{$\begin{array}{l}\text { (+): An increase in payment services } \\
\text { smooths the payment system, thus } \\
\text { promotes overall stability. } \\
\text { (-): Payments expansion, especially } \\
\text { outside the banking system, results in } \\
\text { financial frauds and deteriorate public } \\
\text { trust in the financial system. }\end{array}$} \\
\hline & $\begin{array}{l}\text { Electronic payments } \\
\text { used to make pay- } \\
\text { ment ( } \% \text { age } 15+)\end{array}$ & ELP & $\begin{array}{l}\text { GFDD, } \\
\text { Global Fin- } \\
\text { dex }\end{array}$ & $+/-$ & \\
\hline \multirow[t]{2}{*}{ H5 } & $\begin{array}{l}\text { ATMs per } \\
1,000 \mathrm{sq} \mathrm{km}\end{array}$ & ATM1 & World Bank & $+/-$ & \multirow{4}{*}{$\begin{array}{l}(+) \text { Geographic and demographic } \\
\text { access for savings and deposits is good } \\
\text { for institution capital bases } \\
(-) \text { Geographic and demographic access } \\
\text { for credit may result in higher default } \\
\text { risk. }\end{array}$} \\
\hline & $\begin{array}{c}\text { Bank branches per } \\
1,000 \mathrm{sq} \mathrm{km}\end{array}$ & BRAN1 & World Bank & $+/-$ & \\
\hline \multirow[t]{2}{*}{$\mathrm{H} 6$} & $\begin{array}{c}\text { ATMs per } 100,000 \\
\text { adults }\end{array}$ & ATM2 & World Bank & $+/-$ & \\
\hline & $\begin{array}{c}\text { Bank branches per } \\
100,000 \text { adults }\end{array}$ & BRAN2 & World Bank & $+/-$ & \\
\hline
\end{tabular}

widely used by many scholars in the studies of financial development and economic growth and is found to have a positive impact on economic growth.

Lastly, the real interest rate is controlled in this model. Akbas (2015) obtained a low level of the causal relation between the real interest rate and economic growth. In this study, the author expects that the lower the interest rate means there are more chances for individuals to avail of credit facilities, which leads to a positive impact on financial stability. Details on how to calculate the variables are presented in the Appendix.

\subsection{Model Specification}

Based on previous empirical findings and the selection of variables, the following regression model will be formulated in the research:

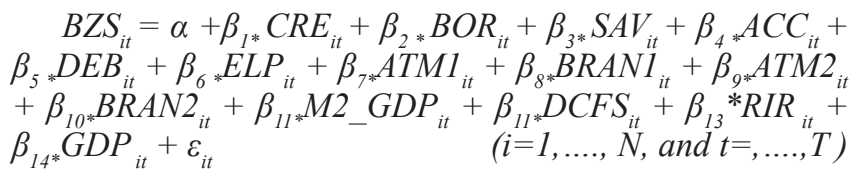

The dependent variable is Bank Z-score, measured by $(\mathrm{ROA}+$ (equity/assets))/standard deviation of ROA. ROA, equity, and assets are country-level aggregate figures calculated from underlying bank-by-bank unconsolidated data from Bankscope. The independent variables include 10 variables as mentioned in Table 1 . Control variable is a vector of broad money per GDP (M2_GDP), Domestic credit provided by financial sector (DCFS), Real interest rate of the country (RIR), GDP per capita growth (GDP). Finally, $\varepsilon_{i t}$ is the error term capturing the effects of omitted variables and other factors that are not included in the model; $\mathrm{i}$ and $\mathrm{t}$ is the country and time characteristic respectively. 
We have applied fixed effects regression, random effects regression for the equation above. To enhance the robustness of the model, the Feasible Generalized Least Squares (FGLS) regression is therefore adopted as the solution for the REM. Since the time factor of the dataset presents gaps between years, the test for serial correlation in the error term $\varepsilon_{i t}$ is unable to conduct. However, model misspecification examinations such as Multicollinearity and Heteroskedasticity are still sufficiently conditional to perform in this model.

\section{Results}

\subsection{Descriptive Analysis}

Table 2 summarizes the descriptive statistical information of the variables in the regression model of 42 countries in Asia in the periods: 2011, 2014 and 2017.

In terms of the dependent variable, the Bank Z-score has the highest value of 49.8068 in Japan and the lowest value of 0.1196 in Tajikistan. The mean value of Bank Z-score in Asian countries is 14.68093 . The volatility from the mean value is over 12 points, showing that the financial stability level varies strongly across the region.

Regarding independent variables, among usages of financial services indicators, account ownership has the largest mean value, followed by payment, saving and credit services respectively. This indicates that formal accounts in financial institutions are mostly used by individual users in Asian countries. Also, Asian residents in general have a tendency to save rather than to borrow. The minimum value of 0 in CRE, ELP, ATM1, ATM2 shows that there are some countries in Asian whose citizens having no usage of credit card and digital payment, which is both in Turkmenistan.

With access to financial system variables, it can be seen that Myanmar residents have no access to ATM banking outlets. The remaining countries vary significantly with each other in the number of bank branches and ATMs, both geographically and demographically. Notably, Hong Kong has the highest number of ATMs and physical bank branches per 1,000 sq km, while Korea and Mongolia share the highest number of ATMs and physical bank branches per 100,000 adults. The dimensions also observe another strong volatility of these variables from the mean values, indicating that the distribution of financial services outlets is extremely different among countries.

\subsection{Empirical Results}

Three regression techniques following panel data, including pooled OLS (POLS), fixed effects model (FEM) and the random effects model (REM) will be conducted. Table 3 shows the regression results obtained from FEM and REM techniques to estimate the influences of financial inclusion indicators on financial stability in Asia. After conducting model specification tests, it can be concluded that

Table 2: Descriptive statistics

\begin{tabular}{|c|c|c|c|c|c|}
\hline Variables & Obs & Mean & Minimum & Maximum & Sd \\
\hline BZS & 126 & 14.68093 & 0.1196 & 49.8068 & 12.06353 \\
\hline CRE & 126 & 18.90504 & 0 & 79.66151 & 20.98978 \\
\hline BOR & 126 & 13.55738 & 0.4190768 & 79.66151 & 7.699108 \\
\hline SAV & 126 & 20.48231 & 0.1172974 & 66.90308 & 16.61168 \\
\hline ACC & 126 & 52.07057 & 0.4049115 & 98.24339 & 16.61168 \\
\hline DEB & 126 & 34.3631 & 0.2694821 & 91.84729 & 16.61168 \\
\hline ELP & 126 & 28.46458 & 0 & 90.7611 & 16.61168 \\
\hline ATM1 & 126 & 170.5134 & 0 & 2975.048 & 504.387 \\
\hline ATM2 & 126 & 46.25912 & 0 & 281.268 & 42.67366 \\
\hline BRAN1 & 126 & 100.5967 & 0.1537208 & 1428.98 & 321.5034 \\
\hline BRAN2 & 126 & 14.86849 & 1.64474 & 71.6071 & 12.487 \\
\hline M2_GDP & 126 & 88.62715 & 19.72928 & 376.5244 & 66.24182 \\
\hline DCFS & 126 & 62.09245 & 3.59848 & 162.676 & 38.60668 \\
\hline RIR & 126 & 5.376058 & -10.8084 & 30.52537 & 5.80135 \\
\hline GDP & 126 & 2.661405 & -15.03783 & 15.21528 & 3.969924 \\
\hline
\end{tabular}


the REM contains multicollinearity and heteroskedasticity issues that prevent the precise estimation of the standard errors, consequently cause incorrect hypothesis tests about the significance of estimated coefficients. To eliminate these errors and enhance the robustness of the model, the Feasible Generalized Least Squares (FGLS) regression is therefore adopted as the solution for the REM.

Table 3 also displays the regression results of FGLS estimation approach. In general, the model is more significant in the circumstance of BZS dependent variable. The variables including CRE, BOR, ACC, SAV, DEB, ELP, BRAN1, ATM2, BRAN2 are significant at $1 \%$ and $5 \%$ levels.

H1 Hypothesis: H1 hypothesis presents that increased credit usages through financial inclusion may positively or negatively affect Z-score. In this hypothesis, the two effects both appear in the model, in which the coefficient of CRE is 0.122 , and coefficient of BOR is -0.183 . Both variables are significant at $1 \%$ levels and have contradicted signs to each other, but the difference in signs is still reasonable as explained by literature.

H2 Hypothesis: $\mathrm{H} 2$ hypothesis predicts a positive influence of SAV to BZS, which means a higher percentage in formal savings at financial institutions leads to higher Bank Z-score. The research result identifies a similar relationship between two variables, in which the coefficient of SAV is positively significant at $5 \%$ level. The actual sign of SAV is comparable to the expected sign before regression, as well as theoretical and empirical literature about the positive impact of savings on financial stability.

H3 Hypothesis: H3 hypothesis presents that a positive linkage on Bank Z-score should be obtained by account usage at financial institutions. The regression outcome also agrees with this notion via a positive sign of ACC. The coefficient equals 0.087 and significant at $1 \%$.

H4 Hypothesis: H4 hypothesis states that an increase in the percentage of payment services usage, including the percentage of respondents having a debit card (denoted by DEB), and the percentage of respondents using E-payments in the last 12 months (denoted by ELP), could create either positive or negative impact on Bank Z-score. The outcomes from the regression indicate that while DEB has positive and significant impacts on Bank Z-score, the effect of ELF is in the opposite direction at $1 \%$ significant level.

H5 and H6 Hypothesis: These hypotheses look at both sides of the relationship between greater geographical and demographical access and Bank Z-score. It can be obtained from the model that all variables representing the hypotheses are significant, and have positive signs. More specifically, the coefficients are respectively 0.002 (for ATM1), 0.008 (for BRAN1), 0.086 (for ATM2), and 0.084 (for BRAN2) (see Table 4).
Table 3: Financial inclusion and financial stability in Asian countries

\begin{tabular}{|c|c|c|c|}
\hline \multirow{2}{*}{ CRE } & \multicolumn{3}{|c|}{ Bank Z-score (BZS) } \\
\cline { 2 - 4 } & $\begin{array}{c}0.159^{* *} \\
(2.98)\end{array}$ & $\begin{array}{c}0.170^{* *} \\
(3.98)\end{array}$ & $\begin{array}{c}0.122^{* * *} \\
(3.54)\end{array}$ \\
\hline BOR & $\begin{array}{c}-0.070 \\
(-0.61)\end{array}$ & $\begin{array}{c}-0.195^{*} \\
(-2.23)\end{array}$ & $\begin{array}{c}-0.183^{* *} \\
(-3.8)\end{array}$ \\
\hline SAV & $\begin{array}{c}-0.064 \\
(-0.79)\end{array}$ & $\begin{array}{c}0.047 \\
(0.72)\end{array}$ & $\begin{array}{c}0.104^{* *} \\
(3.03)\end{array}$ \\
\hline ACC & $\begin{array}{c}-0.014 \\
(-0.27)\end{array}$ & $\begin{array}{c}0.069 \\
(1.54)\end{array}$ & $\begin{array}{c}0.087^{* * *} \\
(4.68)\end{array}$ \\
\hline DEB & $\begin{array}{c}0.014 \\
(0.23)\end{array}$ & $\begin{array}{c}0.031 \\
(0.66)\end{array}$ & $\begin{array}{c}0.051^{* *} \\
(3.14)\end{array}$ \\
\hline ELP & $\begin{array}{c}-0.002 \\
(-0.04)\end{array}$ & $\begin{array}{c}-0.088^{*} \\
(-2.06)\end{array}$ & $\begin{array}{c}-0.131^{* *} \\
(-4.96)\end{array}$ \\
\hline ATM1 & $\begin{array}{c}0.004^{* *} \\
(2.68)\end{array}$ & $\begin{array}{c}0.003^{* *} \\
(2.70)\end{array}$ & $\begin{array}{c}0.002^{*} \\
(2.53)\end{array}$ \\
\hline BRAN1 & $\begin{array}{c}0.012^{* *} \\
(3.29)\end{array}$ & $\begin{array}{c}0.010^{* *} \\
(3.66)\end{array}$ & $\begin{array}{c}0.008^{* * *} \\
(6.11)\end{array}$ \\
\hline justified by the Hausman test. Dependent variable is bank Z score. \\
Z-values are in parentheses. \\
financial stability in Asian countries
\end{tabular}


Table 4: Summary of final estimation

\begin{tabular}{|l|c|c|c|c|}
\hline \multirow{2}{*}{} & \multicolumn{4}{|c|}{ Dependent variable (BZS) } \\
\cline { 3 - 5 } & \multirow{2}{*}{ Hypothesis } & $\begin{array}{c}\text { Expected } \\
\text { sign }\end{array}$ & Result & Conclusion \\
\hline CRE & \multirow{2}{*}{$\mathrm{H} 1$} & $+/-$ & + & Significant \\
\cline { 3 - 5 } BOR & $\mathrm{H} 2$ & $+/-$ & - & Significant \\
\hline SAV & $\mathrm{H} 3$ & + & + & Significant \\
\hline ACC & \multirow{2}{*}{$\mathrm{H} 4$} & $+/-$ & + & Significant \\
\cline { 3 - 5 } DEB & \multirow{2}{*}{$\mathrm{H} 5$} & $+/-$ & - & Significant \\
\hline ELP & & $+/-$ & + & Significant \\
\hline ATM1 & & + & + & Significant \\
\hline BRAN1 & & $+/-$ & + & Significant \\
\hline ATM2 & \multirow{2}{*}{$\mathrm{H} 6$} & $+/-$ & + & Significant \\
\hline BRAN2 & & & &
\end{tabular}

\section{Discussion}

The mixed effects of credit services usage, reflected by opposite signs of credit variables to financial systems' stability (Bank Z-score), shows that the linkage between these variables is not simply straight-linear, but more nonlinear. Up to a certain level, an increase in formal household credit can boost economic growth and financial stability, especially through the decrease in default probabilities of financial institutions. However, if the credit share exceeds that level, the influences on stability will turn negative. The negative effects might result from excessive credit supply to the household sector that reduces lending standards and increases delinquencies from overleveraged borrowers. This, consequently, leads to a financial outburst where credit contraction from cautious credit availability and deterioration of asset quality tend to support each other, making credit balances more adverse and impaired asset ratio increase sharply. This result implies that the diversification effect of assets promotes stability at a certain point, however, higher shares of credit results in a concentration of asset rather than diversification, making the impact becomes negative for stability. In comparison to other findings, this result is consistent with that of Morgan and Zhang (2015) and Sahay et al. (2015) who also argued the quasi-normal relationship between credit expansion and financial stability.

The impacts of formal savings (SAV) and account usage (ACC) at financial institutions are consistent with the proposed hypotheses, which advocate the positive influences on Bank Z-score. A positive sign of SAV means an increase in domestic saving proportion among adults leads to a better Bank Z-scores. Correlated deposit withdrawals could be mitigated if bank deposits are more diversified by the principle of large numbers. Greater diversification of deposits could be achieved by enabling a broader access to and use of bank saving services. Based on this expectation, broader financial inclusion in deposits could considerably improve resilience of banking sector funding and, thus, overall financial stability. Also, positive effect of account usage variable (ACC) on financial stability implies that higher account penetration in institutional level is equivalent to a higher stabilized financial system in Asian countries. Account ownership helps to facilitate other financial services and promote the effectiveness of financial institutions. These relationships are well explained by related literature of Hawkins (2006), Cull et al., (2012) and Han and Melecky (2013).

In terms of payment services influences, DEB (the percentage of adults who have a debit card) has positive and significant impacts on Bank Z-score. Meanwhile, the empirical results show the negative effect of ELP variable (the percentage of adults who used electronic payments). Reasons for this might come from the fact that a rising trend towards electronic payment or cashless payments in China, Japan, Singapore and Southeast Asia countries change the central banks' domination in the clearing system, from which central banks control and implement monetary policies using the information regarding interbank payments (Loh, 2018). As digital non-bank payment providers are increasing, middleman channel between customers and banks are shifting to these entities, leading to (i) more cash payments moving from bank clearing system and facilitating an existing independent clearing system for small payments concurrently with the interbank clearing system supervised by the central banks. Information from such transactions can incentivize these providers which ultimately influences consumer behaviors to their own advantages and increase consumer protection risks where consumer privacy and security in financial transactions cannot be handled; (ii) fee-based digital services supplied by these companies can result in their rising money market funds that may trigger disturbances in countries' money markets and disrupt the financial systems by any of their movements; and (iii) central banks' difficulties to control capital flows across borders since payment transactions can be settled overseas with higher accommodative provisions, which leads to the issues of disguised capital outflows and speculation with the rising risk of price volatility. This view is consistent with the findings of Resendiz (2018).

Regarding the access dimension, generally, four variables representing geographic and demographic accessibility are significant at $10 \%$ and 5\%. Particularly, BRAN1 and ATM2 are significant at $1 \%$ with positive signs, showing that higher number of bank branches and ATMs locally is compatible to higher Bank Z-score. A high level of demographic penetration 
and geographic availability suggests easier access from customers to banking services (Beck \& Kunt, 2005) and consequently support financial resilience. It can be said that access to the financial system illustrates an overall positive to financial stability, which is consistent with the findings of Ghosh (2008).

In terms of control variables, broad money to GDP ratio through M2_GDP variable indicates the significantly positive impactonfinancialstabilityatasignificantlevelof $1 \%$. Thisproves the vital role of money supply for the stability of the financial sector in Asian countries. Meanwhile, the regression results show that other macro-economic factors including Domestic Credit Provided by Financial Sector (DCFS), GDP per capita (GDP), real interest rate (RIR) are not statistically significant.

\section{Conclusion}

This paper has investigated the linkage between financial inclusion and financial stability to examine whether the two mutually reinforce or substantially eliminate each other. The literature suggests that a higher level of financial inclusion can positively or negatively impact financial stability. In which, positive effects include: more stable and diverse funding bases of financial institutions, more efficient and extensive financial intermediation, increased capacity to overcome vulnerabilities and disturbances, etc. Meanwhile, negative effects support the ideas of rising shocks from excessive credit expansion to uncreditworthy individuals, deterioration of credit standards, erosion of institutions' reputation and increasing unregulated financial entities that can destabilize the financial systems.

Financial inclusion data of researched countries in Asia were found to be problematic due to the short span and scarcity. However, despite a relatively small number of observations, the author was able to conduct panel data regression approach, control for misspecification errors, and finally produce a robust final model that reflected the relationship of the variables. From the analysis of estimated results displayed in Section 5, there are some main concluded findings as follows: (i) usages of credit and payment services have a mixed impact on financial stability; (ii) usage of saving service and account has a positive impact on financial stability; and (iii) population-based and area-based access to financial institutions in general have positive impacts on financial stability. Previous empirical research tended to observe direct positive or negative influences of more inclusion on financial stability, which means that the two can be complementary or trade-off. This paper, on the other hand, supports the two notions at the same time. Specifically, the author finds evidence that an increase in geographic and demographic accessibility to financial system aids financial stability. Also, not all usage of financial services can support financial stability in Asian countries. Some indicators such as payment usage and credit usage even resulted in potential side-effects, while the use of saving services again enhanced the resilience of financial systems. These results also offer policymakers insightful information to strengthen the orientation in building financial inclusion strategy for each country in the Asian region.

\section{References}

Ahmad, D. (2018). Financial inclusion and financial stability: Survey of the Nigeria's financial system. International Journal of Research in Finance and Management, 1(2), 47-54.

Akbas, Y. (2015). Financial development and economic growth in emerging market: bootstrap panel causality analysis. Theoretical and Applied Economics, 22(2015), 171-186.

Ardic, O., Imboden, K., \& Latortue, A. (2013). Financial access 2012: Getting to a more comprehensivepicture; Access to Finance Forum Reports by CGAP and its Partners (Vol. 6). Washington, DC:

Beck, T., \& Kunt, A. (2005). Reaching out: Access to and use of banking services across countries. World Bank Policy Research Working Paper Series 3754.

Blundel, R., \& Bond, S. (1998). Initial conditions and moment restrictions in dynamic panel data models. Journal of Econometrics, 87, 115-143.

Bofondi, M., \& Giorgio, G. (2006). Informational Barriers to Entry into Credit Markets. Review of Finance, 10, 39-67,

Cihak, M., Mare, D., \& Melecky, M. (2016). The Nexus of Financial Inclusion and Financial Stability A Study of TradeOffs and Synergies. World Bank Policy Research Working Paper Series 7722.

Cull, R. \& Kunt, A. (2012). Financial Inclusion and Stability: What Does Research Show? World Bank Other Operational Studies 9443

Dienillah, A., Anggraeni. L \& Sahara. (2018). Impact Of Financial Inclusion On Financial Stability Based On Income Group Countries, Bulletin of Monetary Economics and Banking, Bank Indonesia, 20(4), 1-14.

ECB (2012). Financial Stability Review. What is Financial Stability? Frankfurt: European Central Bank

García, C. (2016). Can financial inclusion and financial stability go hand in hand? Economic Issues Journal Articles, Economic Issues, 21(2), 81-103.

Ghosh, S. (2008). Financial Inclusion and Financial Fragility: An Empirical Note. MPRA Paper 24252, University Library of Munich, Germany.

GPFI (2011). The First G20 Global Partnership for Financial Inclusion (Gpfi) Forum. Forum Report.

Han, R. \& Melecky, M. (2013). Financial Inclusion for Stability: Access to Bank Deposits and the Deposit Growth during the Global Financial Crisis. World Bank Policy Research Working Paper Series 6577. 
Hannig, A., \& Jansen, S. (2010). Financial Inclusion and Financial Stability: Current Policy Issues. Finance Working Papers 23124, East Asian Bureau of Economic Research.

Hawkins, P. (2006). Financial Access and Financial Stability. Research paper for the Bank for International Settlements.

Igan, D. \& Pinheiro, M. (2011). Credit Growth and Bank Soundness: Fast and Furious? IMF Working Papers 11/278, International Monetary Fund.

Khan, S. (2011). H R Khan: Financial inclusion and financial stability: are they two sides of the same coin? Address at $B A N C O N$, organized by the Indian Bankers Association and Indian Overseas Bank, Chennai,

Loh, J. (2018). E-payments in Asia - regulating innovation and innovative regulation. Address at the Central Bank Payments Conference, Singapore

Mehrotra, A., \& Yetman, J. (2015). Financial inclusion - issues for central banks. BIS Quarterly Review. Bank for International Settlements

Morgan, P. \& Pontines, V. (2014). Financial Stability and Financial Inclusion. Finance Working Papers 24278, East Asian Bureau of Economic Research.

Morgan, P. \& Zhang, Y. (2015). Mortgage Lending and Financial Stability in Asia. ADBI Working Papers 543, Asian Development Bank Institute.
Ozili, P. (2018). Impact of Digital Finance on Financial Inclusion and Stability. MPRA Paper 84771, University Library of Munich, Germany.

Park, C. \& Mercado, R. (2018). Financial Inclusion: New Measurement and Cross-Country Impact Assessment. Working Papers wp29, South East Asian Central Banks (SEACEN) Research and Training Centre.

Prasad, E. (2010). Financial Sector Regulation and Reforms in Emerging Markets: An Overview. NBER Working Papers 16428, National Bureau of Economic Research, Inc.

Resendiz, R. (2018). The Role of Payment Systems and Services in Financial Inclusion: Latin American and Caribbean Perspective. In Bank for International Settlements (ed.), The role of data in supporting financial inclusion policy, volume 47.

Sahay, R., Cihak, M., Barajas, A. \& Gao, Y. (2015). Rethinking Financial Deepening: Stability and Growth in Emerging Markets. IMF Staff Discussion Notes 15/08, International Monetary Fund.

Tran, S. H., \& Nguyen, L. T. (2020). Financial Development, Business Cycle and Bank Risk in Southeast Asian Countries. Journal of Asian Finance, Economics and Business, 7(3), 127135. https://doi.org/10.13106/jafeb.2020.vol7.no3.127

World Bank (2014). Global Financial Development Report 2014: Financial Inclusion. Washington, DC 


\section{Appendix}

A1: Correlations of the variables

\begin{tabular}{|c|c|c|c|c|c|c|c|c|c|c|c|c|c|c|}
\hline & BZS & CRE & BOR & SAV & $\mathrm{ACC}$ & DEB & ELP & ATM1 & ATM2 & BRAN1 & BRAN2 & $\begin{array}{c}\text { M2 } \\
\text { GDP }\end{array}$ & DCFS & RIR \\
\hline BZS & 1.000 & & & & & & & & & & & & & \\
\hline CRE & 0.656 & 1.000 & & & & & & & & & & & & \\
\hline BOR & -0.000 & 0.150 & 1.000 & & & & & & & & & & & \\
\hline SAV & -0.000 & 0.706 & 0.181 & 1.000 & & & & & & & & & & \\
\hline ACC & 0.647 & 0.622 & 0.352 & 0.832 & 1.000 & & & & & & & & & \\
\hline DEB & 0.557 & 0.491 & 0.270 & 0.718 & 0.845 & 1.000 & & & & & & & & \\
\hline ELP & 0.556 & 0.644 & 0.316 & 0.754 & 0.837 & 0.815 & 1.000 & & & & & & & \\
\hline ATM1 & 0.540 & 0.373 & -0.009 & 0.313 & 0.298 & 0.293 & 0.247 & 1.000 & & & & & & \\
\hline ATM2 & 0.561 & 0.510 & 0.287 & 0.572 & 0.599 & 0.477 & 0.596 & 0.285 & 1.000 & & & & & \\
\hline BRAN1 & 0.667 & 0.473 & -0.159 & 0.444 & 0.331 & 0.297 & 0.349 & 0.510 & 0.229 & 1.000 & & & & \\
\hline BRAN2 & 0.360 & 0.077 & 0.221 & 0.286 & 0.381 & 0.333 & 0.340 & 0.153 & 0.253 & 0.238 & 1.000 & & & \\
\hline $\begin{array}{l}\text { M2 } \\
\text { GDP }\end{array}$ & 0.612 & 0.429 & -0.104 & 0.555 & 0.450 & 0.433 & 0.432 & 0.398 & 0.282 & 0.663 & 0.209 & 1.000 & & \\
\hline DCFS & 0.042 & 0.429 & 0.003 & 0.038 & 0.066 & \begin{tabular}{|l|}
-0.037 \\
\end{tabular} & 0.142 & -0.114 & 0.239 & -0.027 & -0.035 & 0.180 & 1.000 & \\
\hline RIR & -0.151 & -0.239 & -0.006 & -0.224 & -0.182 & -0.181 & 0.005 & -0.222 & -0.031 & -0.090 & 0.146 & -0.218 & 0.087 & 1.000 \\
\hline GDP & -0.154 & -0.079 & 0.126 & -0.074 & 0.006 & -0.070 & -0.067 & -0.188 & -0.060 & -0.102 & 0.037 & -0.057 & 0.148 & -0.048 \\
\hline
\end{tabular}

A2: List of Asian countries in the research

\begin{tabular}{|c|c|c|c|c|c|}
\hline No & Country & Region & No & Country & Region \\
\hline 1 & Afghanistan & South Asia & 22 & Lao PDR & Southeast Asia \\
\hline 2 & Armenia & Western Asia & 23 & Lebanon & Western Asia \\
\hline 3 & Azerbaijan & Western Asia & 24 & Malaysia & Southeast Asia \\
\hline 4 & Bahrain & Western Asia & 25 & Mongolia & East Asia \\
\hline 5 & Bangladesh & South Asia & 26 & Myanmar & Southeast Asia \\
\hline 6 & Bhutan & South Asia & 27 & Oman & Western Asia \\
\hline 7 & Cambodia & Southeast Asia & 28 & Pakistan & South Asia \\
\hline 8 & China & East Asia & 29 & Philippines & Southeast Asia \\
\hline 9 & Georgia & Western Asia & 30 & Qatar & Western Asia \\
\hline 10 & Hong Kong, China & East Asia & 31 & Saudi Arabia & Western Asia \\
\hline 11 & India & South Asia & 32 & Singapore & Southeast Asia \\
\hline 12 & Indonesia & Southeast Asia & 33 & Sri Lanka & South Asia \\
\hline 13 & Iran, Islamic Rep. & Western Asia & 34 & Syrian Arab Republic & Western Asia \\
\hline 14 & Iraq & Western Asia & 35 & Taiwan, China & East Asia \\
\hline 15 & Israel & Western Asia & 36 & Tajikistan & Central Asia \\
\hline 16 & Japan & East Asia & 37 & Thailand & Southeast Asia \\
\hline 17 & Jordan & Western Asia & 38 & Turkmenistan & Central Asia \\
\hline 18 & Kazakhstan & Central Asia & 39 & United Arab Emirates & Western Asia \\
\hline 19 & Korea, Rep. & East Asia & 40 & Uzbekistan & Central Asia \\
\hline 20 & Kuwait & Western Asia & 41 & Vietnam & Southeast Asia \\
\hline 21 & Kyrgyz Republic & Central Asia & 42 & Yemen, Rep. & Western Asia \\
\hline
\end{tabular}


A3: Description of variables

\begin{tabular}{|c|c|c|}
\hline No & Variable & Definition \\
\hline 1 & CRE & The percentage of adults who report having a credit card (\% age $15+)$ \\
\hline 2 & BOR & $\begin{array}{l}\text { The percentage of adults who report borrowing any money from a bank, credit union, } \\
\text { microfinance institution, or another financial institution such as a cooperative in the past } 12 \\
\text { months }(\% \text { age } 15+) \text {. }\end{array}$ \\
\hline 3 & SAV & $\begin{array}{l}\text { The percentage of adults who report saving or setting aside any money by using an account } \\
\text { at a formal financial institution such as a bank, credit union, microfinance institution, or } \\
\text { cooperative in the past } 12 \text { months }(\% \text { age } 15+) \text {. }\end{array}$ \\
\hline 4 & $\mathrm{ACC}$ & $\begin{array}{l}\text { The percentage of adults with an account (self or together with someone else) at a bank, } \\
\text { credit union, another financial institution (e.g., cooperative, microfinance institution), or the } \\
\text { post office (if applicable) including respondents who reported having a debit card (\% age } \\
15+\text { ). }\end{array}$ \\
\hline 5 & DEB & The percentage of adults who report having a debit card (\% age $15+)$. \\
\hline 6 & ELP & $\begin{array}{l}\text { The percentage of adults who used electronic payments (payments that one makes or that } \\
\text { are made automatically including wire transfers or payments made online) in the past } 12 \\
\text { months to make payments on bills or to buy things using money from their accounts (\% age } \\
15+) \text {. }\end{array}$ \\
\hline 7 & ATM1 & The number of automated teller machines (ATMs) per 1, 000 square kilometers \\
\hline 8 & BRAN1 & The number of bank branches per 1, 000 square kilometers \\
\hline 9 & ATM2 & The number of automated teller machines (ATMs) per 100,000 people \\
\hline 10 & BRAN2 & The number of bank branches per 100,000 people \\
\hline 11 & M2_GDP & $\begin{array}{l}\text { The sum of currency outside banks; demand deposits other than those of the central } \\
\text { government; the time, savings, and foreign currency deposits of resident sectors other than } \\
\text { the central government; bank and traveler's checks; and other securities such as certificates } \\
\text { of deposit and commercial paper. }\end{array}$ \\
\hline 12 & DCFS & $\begin{array}{l}\text { Domestic credit provided by the financial sector includes all credit to various sectors on a } \\
\text { gross basis, with the exception of credit to the central government. }\end{array}$ \\
\hline 13 & RIR & The lending interest rate adjusted for inflation as measured by the GDP deflator \\
\hline 14 & GDP & Annual percentage growth rate of GDP per capita based on constant local currency \\
\hline
\end{tabular}

